\title{
Extrathyroidal Release of Thyroid Hormones from Thyroglobulin by J774 Mouse Macrophages
}

\author{
Klaudia Brix and Volker Herzog \\ Institut für Zellbiologie, Rheinische Friedrich-Wilhelms Universität, D-53121 Bonn, Germany
}

\begin{abstract}
Thyroglobulin appears in the circulation of vertebrates at species-specific concentrations. We have observed that the clearance of thyroglobulin from the circulation occurs in the liver by macrophages. Here we show that the thyroid hormones $T_{3}$ and $T_{4}$ were released by incubation of mouse macrophages ( $J 774$ ) with thyroglobulin. Thyroid hormone release was a fast process, with an initial rate of $\sim 20 \mathrm{pmol} \mathrm{T}_{4} / \mathrm{mg}$ per min and $\sim 0.6 \mathrm{pmol} \mathrm{T}_{3} / \mathrm{mg}$ per $\mathrm{min}$, indicating that macrophages preferentially release $T_{4}$. The bulk of released thyroid hormones appeared after 5 min of incubation of macrophages with thyroglobulin, whereas degradation of the protein was detectable only after several hours. During internalization of thyroglobulin, endocytic vesicles and endosomes were reached at $5 \mathrm{~min}$ and lysosomes at $60 \mathrm{~min}$. $T_{4}$ release started extracellularly by secreted proteases and continued along the endocytic pathway of thyroglobulin, whereas $T_{3}$ release occurred mainly intracellularly when thyroglobulin had reached the lysosomes. This shows that the release of both hormones occurred at distinct cellular sites. Our in vitro observations suggest that macrophages in situ represent an extrathyroidal source for thyroid hormones from circulating thyroglobulin. (J. Clin. Invest. 1994.93:13881396.) Key words: thyroid gland • iodoproteins • thyroxine • triiodothyronine $\bullet$ endocytosis
\end{abstract}

\section{Introduction}

Thyroglobulin (TG), ${ }^{1}$ the precursor of the thyroid hormones 3,3',5'-triiodo-L-thyronine $\left(\mathrm{T}_{3}\right)$ and L-thyroxine $\left(\mathrm{T}_{4}\right)$, is synthesized by epithelial cells and stored in the lumina of thyroid follicles. From the studies of Hjort (1), Assem (2), and Roitt and Torrigiani (3), it became clear that the occurrence of TG is not restricted to the thyroid gland but appears also in the circulation of vertebrates at species-specific concentrations (4-6).

Parts of this paper were reported at the Annual Meetings of the American Society for Cell Biology, 8-12 December 1991, Boston, MA, (17) and the German Society for Cell Biology, 15-20 March 1992, Konstanz, Germany (18).

Address correspondence to Dr. Klaudia Brix, Institut für Zellbiologie, Universităt Bonn, Ulrich-Haberland-Str. 61a, D-53121 Bonn, Germany.

Received for publication 9 August 1993 and in revised form 29 November 1993.

1. Abbreviations used in this paper: f.c., final concentration; $\mathrm{T}_{3}$, triiodo-L-thyronine; $\mathrm{T}_{4}$, L-thyroxine; TG, thyroglobulin; TSH, thyroid-stimulating hormone.

J. Clin. Invest.

(c) The American Society for Clinical Investigation, Inc. 0021-9738/94/04/1388/09 \$2.00

Volume 93, April 1994, 1388-1396
Thyroid-stimulating hormone (TSH) stimulation of the thyroid gland results in an increase of plasma TG levels (7), which is also observed in pathological conditions of the thyroid, such as differentiated carcinoma and subacute thyroiditis (for review see reference 4).

We have previously shown that TG reaches the circulation by TSH-regulated transepithelial vesicular transport (transcytosis; 8,9 ). During this process TG does not undergo proteolytic cleavage, thereby reaching the circulation as an intact molecule (10). Clearance of TG from the circulation varies with the state of glycosylation (11). In rats the survival time for asialo-TG was $40 \mathrm{~min}$, whereas native TG persisted for 4.4-9.3 h (12-15). Asialo-TG most probably is internalized by hepatocytes via their galactose receptors (16). There are, however, no reports on the cells involved in the clearance of native TG.

We found Kupffer cells to be the main target cells that internalize native TG after injection into the circulation of mice and rats (17). The internalization of TG was studied in detail on the mouse macrophage-like cell line J774, and a high affinity receptor for TG was isolated and partially characterized (18).

Several authors postulated an extrathyroidal source for thyroid hormones $(19,20)$. Therefore, in this study, a detailed analysis was carried out concerning the rates, kinetics, and mechanisms of thyroid hormone release by J774 cells. The results show that, unexpectedly, partial hydrolysis of TG with release of $\mathrm{T}_{4}$ occurs mainly extracellularly and at early stages of endocytosis, whereas $T_{3}$ release and the proteolysis of TG are slow processes occurring in lysosomes. We conclude that macrophages represent an extrathyroidal source for thyroid hormones from circulating TG.

\section{Methods}

\section{Cell culture}

The murine macrophage-like cell line J774A.1 (21) was obtained from American Type Culture Collection (Rockville, MD) and grown at $37^{\circ} \mathrm{C}$ and $5 \% \mathrm{CO}_{2}$ in DME supplemented with $10 \%$ heat-inactivated ( $30 \mathrm{~min}, 56^{\circ} \mathrm{C}$ ) $\mathrm{FCS}, 100 \mathrm{IU} / \mathrm{ml}$ penicillin $\mathrm{G}, 0.1 \mathrm{mg} / \mathrm{ml}$ streptomycin, and $0.5 \mu \mathrm{g} / \mathrm{ml}$ amphotericin B.

\section{Isolation and purification of bovine TG}

Bovine thyroid glands were obtained from the local slaughterhouse and cut into small fragments. All following steps were performed at $4^{\circ} \mathrm{C}$.

For isolation of TG the tissue fragments were homogenized in PBS supplemented with protease inhibitors ( $1 \mathrm{mM} N$ - $\alpha$-p-tosyl-L-arginine methyl ester, $0.5 \mathrm{mM}$ PMSF, $1 \mu \mathrm{g} / \mathrm{ml}$ antipain, $1 \mu \mathrm{g} / \mathrm{ml}$ pepstatin, 4 $\mu \mathrm{g} / \mathrm{ml}$ aprotinin). After centrifugation ( $30 \mathrm{~min}, 22,000 \mathrm{~g}$; Beckman Instrs., Inc., Palo Alto, $\mathrm{CA}$ ) the supernatant was subjected to ammonium sulfate precipitation ( $35 \%$ for $2 \mathrm{~h}$ and $45 \%$ overnight). The TG fraction was resuspended, cleared by centrifugation ( $20 \mathrm{~min}, 15,000$ $g$ ), and further purified by anion-exchange chromatography using an FPLC device (MonoP HR 5/5; Pharmacia LKB Biotechnology, Uppsala, Sweden). After isocratic elution, the TG fractions (0.4-0.8 M 
$\mathrm{NaCl}$ ) were pooled and desalted (EconoPac ${ }^{\mathrm{TM}}$ 10DG; Bio-Rad Laboratories, Richmond, CA).

\section{In vitro iodination of $T G$}

Iodination of TG with [ $\left.{ }^{125} \mathrm{I}\right] \mathrm{Nal}$ was performed in PBS for $15 \mathrm{~min}$ at room temperature using iodobeads $(22)$. Free $\left[{ }^{125} \mathrm{I}\right] \mathrm{Nal}$ was removed by desalting (see above).

\section{Production of polyclonal antibodies}

Purified TG was used to raise polyclonal antibodies in rabbits according to standard protocols (23). Titers were $1: 16$ using $900 \mu \mathrm{g} / \mathrm{ml} \mathrm{TG}$ as an antigen in Ouchterlony analysis. Dilution (1:200) of the serum recognized $1 \mathrm{ng}$ TG in dot blots.

\section{Alkaline hydrolysis of TG}

Purified TG was hydrolyzed with $\mathrm{NaOH}$ ( $1 \mathrm{~N}$, final concentration [f.c.]) at $110^{\circ} \mathrm{C}$ for $24 \mathrm{~h}$. After neutralization thyroid hormone concentrations were determined by RIA.

\section{Degradation of TG by $\mathrm{J774}$ cells}

Cells were incubated with radioiodinated TG dissolved in culture medium at $4^{\circ} \mathrm{C}$ and $37^{\circ} \mathrm{C}$ for 30 and $120 \mathrm{~min}$, respectively. After washing cells were lysed on ice for $30 \mathrm{~min}$ in lysis buffer consisting of $1 \%$ Triton $\mathrm{X}-100,50 \mathrm{mM}$ Tris/ $\mathrm{HCl}$ (pH 8.0), $150 \mathrm{mM} \mathrm{NaCl}, 0.02 \% \mathrm{NaN}_{3}$ supplemented with $1 \mathrm{mM}$ PMSF, $1 \mu \mathrm{g} / \mathrm{ml}$ aprotinin, $1 \mu \mathrm{g} / \mathrm{ml}$ antipain, 1 $\mu \mathrm{g} / \mathrm{ml}$ pepstatin $\mathrm{A}$, and $1 \mathrm{mM}$ EDTA as protease inhibitors (24). Cell debris was removed by centrifugation $\left(10 \mathrm{~min}, 15,000 \mathrm{~g}, 4^{\circ} \mathrm{C}\right.$; Eppendorf, Hamburg, Germany). Supernatants were assayed for protein concentration and analyzed by SDS-PAGE and fluorography.

Degradation of $T G$ by lysosomal hydrolases of $J 774$ cells

$\mathrm{J} 774$ cells were suspended in $3 \mathrm{mM}$ imidazol supplemented with 0.25 $\mathrm{M}$ sucrose ( $\mathrm{pH} 7.4$ ) and lysed by repeated pipetting through 27-gauge needles. A lysosomal fraction was prepared by differential centrifugation and the lysosomes were lysed on ice with $0.2 \%$ Triton $\mathrm{X}-100$ in PBS ( pH 5.0) for $30 \mathrm{~min}$. Lysosomal enzymes in the supernatants after centrifugation for $10 \mathrm{~min}$ at $15,000 \mathrm{~g}$ (Eppendorf) were incubated with TG ( $76 \mathrm{nM}$, f.c.) for 5,60 , and $240 \mathrm{~min}$ at $37^{\circ} \mathrm{C}$. Degradation of TG was stopped by the addition of sample buffer and analyzed by SDSPAGE and immunoblotting.

\section{Protein assays}

Protein concentrations were determined according to Bradford (25). Lyophilized TG or bovine serum albumin were used as standards.

\section{SDS-PAGE and immunoblotting}

Samples were diluted in sample buffer ( $10 \mathrm{mM}$ Tris $/ \mathrm{HCl}, \mathrm{pH} 7.6,0.5 \%$ SDS, $25 \mathrm{mM}$ DTT, $10 \%$ glycerol, $25 \mu \mathrm{g} / \mathrm{ml}$ bromophenolblue, f.c.) to give final protein concentrations ranging from 1 to $3 \mathrm{mg} / \mathrm{ml}$ and boiled for $3 \mathrm{~min}$. Standard molecular mass markers for silver-stained gels were from Sigma (Deisenhofen, Germany). For Western blots rainbow marker kits were used (Amersham Buchler, Braunschweig, Germany).

Samples were analyzed with a horizontal electrophoresis device (Pharmacia LKB Biotechnology) using gradient SDS-polyacrylamide gels $(5-15 \%)(26)$.

After electrophoresis, the gels were either fixed and silver stained (27) or subjected to fluorography. For the transfer to nitrocellulose (Schleicher \& Schüll, Inc., Dassel, Germany) by Western blotting (28), a semi-dry blotting chamber (Bio-Rad Laboratories) was used. Unspecific binding sites were saturated in a solution containing $6 \%$ casein, $1 \%$ polyvinylpyrrolidon $40,10 \mathrm{mM}$ EDTA in low-salt PBS $(68 \mathrm{mM} \mathrm{NaCl}$, $63 \mathrm{mM} \mathrm{Na}_{2} \mathrm{HPO}_{4}, 12 \mathrm{mM} \mathrm{NaH}_{2} \mathrm{PO}_{4}, \mathrm{pH} 6.8$ ). For detection of TG degradation products, rabbit anti-bovine TG IgG and goat anti-rabbit IgG coupled to horseradish peroxidase were diluted in the blocking solution. Immunoblots were developed in chloronaphthol as a substrate (28) and documented on Agfapan APX 25 (Agfa-Gevaert, Leverkusen, Germany). Fluorography was performed at $-80^{\circ} \mathrm{C}$ on $\mathrm{X}$ OMAT $^{\mathrm{TM}}$ AR films (Eastman Kodak Co., Rochester, NY).

\section{Fixation and labeling for fluorescence and electron} microscopy

Immunofluorescence microscopy. Cells were grown on cover glasses and washed in DME and 10\% FCS. To determine the endocytic pathway in $\mathrm{J} 774$ cells, TG was added to the culture medium at $100 \mathrm{nM}$ (f.c.). After $5 \mathrm{~min}$ of endocytosis at $37^{\circ} \mathrm{C}$ the cells were washed in culture medium without TG $\left(4^{\circ} \mathrm{C}\right)$. Cells were chased in TG-free media for 5-60 min before fixation in methanol and acetone (each for 8 $\mathrm{min},-20^{\circ} \mathrm{C}$ ). After washing cells were blocked with $3 \mathrm{mg} / \mathrm{ml}$ human IgG and $1 \%$ ovalbumin. Cells were incubated with anti-bovine TG antibodies for $90 \mathrm{~min}$ at $37^{\circ} \mathrm{C}$. Fab fragments of goat anti-rabbit IgG coupled to 5-(4,6-dichlorotriazin-2-YL)-aminofluorescein hydrochloride (DTAF) (1:50, $120 \mathrm{~min}, 37^{\circ} \mathrm{C}$; Dianova, Hamburg, Germany) were used as second antibodies.

Immunolabeling for Lamp-1 was performed after fixing the cells in $3 \%$ formaldehyde in $200 \mathrm{mM}$ Hepes for $30 \mathrm{~min}$ at room temperature and subsequent washing in buffer. Cells were incubated with antiLamp-1 antibodies (29) overnight at $4^{\circ} \mathrm{C}$. FITC-goat anti-rat IgG in dilutions 1:50-100 (Dianova) were used as second antibodies.

Cells were mounted on microscope slides and viewed with a fluorescence microscope (Zeiss, Oberkochen, Germany). Micrographs were taken on Kodak TMAX films.

Cryoelectron microscopy (30). To prelabel lysosomes (29), J774 cells were incubated with $\mathrm{BSA}-\mathrm{Au}_{17}$ (in DME supplemented with $10 \%$ FCS, $9 \mathrm{~h}, 37^{\circ} \mathrm{C}$ ) prepared by the method of Slot and Geuze (31) and chased in culture medium without BSA-Au ${ }_{17}\left(20 \mathrm{~h}, 37^{\circ} \mathrm{C}\right)$. Cells were further incubated with TG (see previous section) and fixed with $3 \%$ formaldehyde in $200 \mathrm{mM}$ Hepes ( $\mathrm{pH} 7.4 ; 30-60 \mathrm{~min}$ ). After postfixation in $8 \%$ formaldehyde, the cells were infiltrated with sucrose as a cryoprotectant $(2.3 \mathrm{M})$ and frozen in liquid propane. Ultrathin cryosections were prepared with a cryotome (Reichert-Jung, Wien, Austria ) at $-110^{\circ} \mathrm{C}$ and mounted on pioloform $\mathrm{F}$ and carbon-coated grids. Immunolabeling was performed as described above. Sections were stained with $0.3 \%$ uranyl acetate in $2.7 \%$ polyvinyl alcohol $(10 \mathrm{~min})$ and examined with an electron microscope (EM301; Philips, Kassel, Germany). Photographic film was from Guilleminot (Paris, France).

\section{Detection of thyroid hormones released from $T G$ by J774 cells}

Incubation protocol. Cells were incubated in culture medium with 760 nM TG (f.c.) or without TG. The culture medium was DME supplemented with FCS as a carrier. FCS was depleted before from thyroid hormones by anion exchange chromatography (32). In a first series of experiments cells were incubated with TG for 5,30 , or $60 \mathrm{~min}$. In a second series cells were preincubated with $10 \mathrm{mM} \mathrm{NH}_{4} \mathrm{Cl}$ for $2 \mathrm{~h}$ and further incubated in culture medium containing $\mathrm{TG}$ and $\mathrm{NH}_{4} \mathrm{Cl}$ for 5 , 30 , and $60 \mathrm{~min}$. All incubations were triplicates.

The supernatants of cells were removed after incubation for the indicated time intervals and cleared by centrifugation. Cells were lysed on ice for $30 \mathrm{~min}$ in lysis buffer (see Degradation of TG by J774 cells) and cell debris was removed by centrifugation. Samples were assayed for protein concentrations using BSA and purified TG as standards.

Detection of thyroid hormones by TLC. Cell lysates were extracted by overlaying with $n$-butanol ( $30 \mathrm{~min}$, room temperature) and the hydrophobic phase was evaporated to dryness. The remnants were dissolved in $0.1 \mathrm{~N} \mathrm{NaOH}$ and subjected to TLC on silica gels (HPTLC; Merck, Darmstadt, Germany). Separation was performed in a solvent consisting of $n$-butanol/methanol $/ 20 \%$ ammoniumhydroxide $(80: 20: 20$ [ $\mathrm{vol} / \mathrm{vol}]) . \mathrm{T}_{3}$ and $\mathrm{T}_{4}(5 \mu \mathrm{g}$ each; Sigma $)$ dissolved in $\mathrm{NaOH}$ were used as standards. Phenolic amino acids were visualized by spraying the dry plates with $20 \% \mathrm{Na}_{2} \mathrm{CO}_{3}$ and Folin-Ciocalteau reagent (33). Developed thin layer chromatograms were documented on APX-25 films (Agfa-Gevaert).

Quantitation of thyroid hormones released by $J 774$ cells by RIA. To quantitate thyroid hormones in supernatants and lysates of $\mathrm{J} 774$ cells, a commercially available RIA for total $T_{3}$ and $T_{4}$ was used (Henning, Berlin, Germany) $(5,6,34)$. Each sample was measured in duplicates. 
Aliquots of media containing TG before incubation or lysis buffer were used as blanks.

Values for thyroid hormone contents of the different samples were corrected for protein concentrations. Unless indicated, control values (preparations without TG incubation) were subtracted from sample values and results given in picomoles hormone/mg cell protein, where $1 \mathrm{mg}$ cell protein corresponds to $19 \times 10^{6}$ cells $(35)$. Mean values were calculated from three independent experiments. Thyroid hormone release rates were calculated from the sum of thyroid hormone contents in supernatants and cell lysates divided by the incubation time and given as picomoles hormone/mg per min.

Contribution of secreted proteases to total thyroid hormone release. In cultures of starved $\mathbf{J} 774$ cells the medium was renewed several times to remove cell debris. Cells were incubated with medium (DME) for 16 $\mathrm{h}$ at $37^{\circ} \mathrm{C}$. Supernatants of cells were cleared by centrifugation. In cellfree assays TG was added ( $760 \mathrm{nM}$, f.c.) to the conditioned media and further incubated for $30 \mathrm{~min}$ at $37^{\circ} \mathrm{C}$ with or without a protease inhibitor cocktail consisting of $1 \mathrm{mM}$ PMSF, $1 \mu \mathrm{g} / \mathrm{ml}$ aprotinin, and $5 \mathrm{mM}$ iodoacetamide. Thyroid hormone contents of such media were determined by RIA and corrected for TG present in the assay. Control values, e.g., nonconditioned media supplemented with $\mathrm{TG}$ and reacted at $37^{\circ} \mathrm{C}$ for the same time interval, were subtracted.

The contribution of secreted proteases to total thyroid hormone release was quantitated in a second series of experiments. Cells were incubated with medium (DME supplemented with FCS) for $5 \mathrm{~min}$ at $37^{\circ} \mathrm{C}$. TG was added ( $760 \mathrm{nM}$, f.c.) to the supernatants and further incubated in the presence or absence of cells for $5 \mathrm{~min}$ at $37^{\circ} \mathrm{C}$. Thyroid hormone contents of supernatants and cell lysates were measured by RIA, and the sum of both was corrected for TG present in the assay. Control values, e.g., the same preparations supplemented with TG as above but without the second incubation at $37^{\circ} \mathrm{C}$, were subtracted.

Thyroid hormone transport. For the analysis of thyroid hormone transport mechanisms across the plasma membrane, vital and formaldehyde-fixed $\mathbf{J} 774$ cells were incubated with culture medium (DME supplemented with $10 \%$ FCS) containing $160 \mathrm{ng} / \mathrm{ml} \mathrm{T}_{4}$ and $4 \mathrm{ng} / \mathrm{ml}$ $\mathrm{T}_{3}$ (f.c.) for 0-60 min at $37^{\circ} \mathrm{C}$. Media and cells were processed for RIA as described earlier. To determine the loss of thyroid hormones by unspecific adsorption, culture dishes without cells were incubated with the same medium for $0-60 \mathrm{~min}$ at $37^{\circ} \mathrm{C}$. Media were cleared by centrifugation and analyzed by RIA.

\section{Results}

Previous observations have shown that Kupffer cells are the main target cells that internalize circulating TG (17). In this study, the mouse macrophage-like cell line $\mathrm{J} 774$ was used to analyze the interaction with TG.

Thyroid hormone release from $T G$. Incubation of $\mathrm{J} 774$ cells with TG for time intervals from 5 to $60 \mathrm{~min}$ at $37^{\circ} \mathrm{C}$ resulted in the release of thyroid hormones detectable by TLC of butanol extracts from cell lysates (Fig. 1, lanes 2 and 3). Thyroid hormones were not found in lysates of control cells incubated in the absence of TG (Fig. 1, lane 1).

As thin layer chromatography did not allow us to distinguish between $T_{3}$ and $T_{4}$, a specific RIA was used. Alkaline hydrolysis of $T G$ revealed a $T_{4} / T_{3}$ ratio of 4 , which was similar to the expected values of 3-4 calculated from the hormone content per molecule TG (Table I). However, the values resulting from the incubation of cells with TG were much higher. The absolute amount of $\mathrm{T}_{4}$ released from TG at $5 \mathrm{~min}$ exceeded the values for $T_{3}$ by a factor of $\sim 36$ in cell lysates and of $\sim 38$ in the culture medium (Table I).

The release of thyroid hormones was observed only for the initial period ( $5 \mathrm{~min}$ ) of incubation of $\mathrm{J} 774$ cells with TG (Fig. 2 ). In the culture medium about four to five times more $T_{3}$ or
TG

$\min$

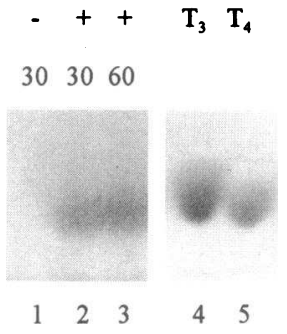

Figure 1. Thyroid hormone release from TG by $\mathrm{J} 774$ cells (TLC). TLC of thyroid hormones in butanol extracts of J774 cells incubated without (lane 1 ) or with TG (lanes 2 and 3 ) at $37^{\circ} \mathrm{C}$ for 30 (lanes 1 and 2 ) and $60 \mathrm{~min}$ (lane 3 ). $\mathrm{T}_{3}$ (lane 4) and $\mathrm{T}_{4}$ (lane 5) were used as standards. Sol-

vent: butanol/methanol /20\% ammoniumhydroxide. Phenolic amino acids were visualized with Folin-Ciocalteau reagent spray. Note the presence of thyroid hormones at rf values of $0.43-0.45$ in extracts of TG-incubated cells.

$\mathrm{T}_{4}$ were detected than in cells. At later time points $(30-60 \mathrm{~min})$ the cellular levels for $\mathrm{T}_{4}$ decreased (Fig. 2 a, filled circles), whereas the cellular levels for $\mathrm{T}_{3}$ increased (Fig. $2 b$, filled triangles).

The endocytic pathway of TG. TG was incubated with $\mathrm{J} 774$ cells for $5 \mathrm{~min}$ at $37^{\circ} \mathrm{C}$, chased in TG-free media, and identified immunocytochemically in endocytic vesicles. For identification of the endocytic compartments J774 cells were immunolabeled with antibodies against the lysosomal membrane glycoprotein Lamp-1. For electron microscope studies lysosomes of $\mathrm{J} 774$ cells were prelabeled with $\mathrm{BSA}-\mathrm{Au}_{17}$.

Within 5 min of incubation TG was detected intracellularly. Chasing for 5 min resulted in the accumulation of TG within three to six vacuoles per cell (Fig. $3 a^{\prime}$, arrows) which decreased in number at longer chase periods (one to two large vesicles at $30 \mathrm{~min}$ ). TG-containing vacuoles were distributed throughout the cytoplasm of $\mathrm{J} 774$ cells (Fig. 3, $a$ and $a^{\prime}$ ). Electron microscope immunocytochemistry revealed large vacuoles with a diameter of 2-5 $\mu \mathrm{m}$ (Fig. 4, $a$ and $b, E N$ ). Immunocytochemical detection of TG resulted in the localization of immunogold particles $\left(\mathrm{Au}_{5}\right)$ on the inner membrane surface of these vacuoles, whereas immunogold particles were absent from their matrix. The vacuoles were negative for Lamp-1 (Fig. 3, $c$ and $c^{\prime}$, asterisk) but their majority was surrounded by Lamp-1-positive small vesicles (Fig. 3, $c$ and $c^{\prime}$, arrowheads). Electron microscopy revealed $\mathrm{BSA}-\mathrm{Au}_{17}$-containing lysosomes in close proximity to TG-containing vacuoles (Fig. 4, $a$ and $b$ ). By morphology and by the lack of Lamp-1 and BSA-Au ${ }_{17}$, these TG-containing vacuoles were identified as endosomes.

Table I. Thyroid Hormone Release from TG

\begin{tabular}{lc}
\hline & $\begin{array}{c}\mathrm{T}_{4} / \mathrm{T}_{3} \\
\text { ratio }\end{array}$ \\
\hline $\begin{array}{l}\text { Thyroid hormone content of TG, expected values* } \\
\text { Thyroid hormone release by alkaline hydrolysis of TG }\end{array}$ & $3-4$ \\
Thyroid hormone release within the initial incubation \\
$\quad$ (5 min) of cells with TG:
\end{tabular}

Thyroid hormone release from TG was determined by RIA. Absolute amounts of thyroid hormones (mean \pm SE) detected in lysates of 19 $\times 10^{6} \mathrm{~J} 774$ cells were $19.1 \pm 8.1 \mathrm{pmol} \mathrm{T}_{4}$ and $0.53 \pm 0.25 \mathrm{pmol} \mathrm{T}_{3}$ at 5 min, whereas four to five times higher levels were detected in the culture medium (87.2 $\pm 11.0 \mathrm{pmol} \mathrm{T}_{4}$ and $\left.2.27 \pm 0.42 \mathrm{pmol} \mathrm{T}_{3}\right)$. * Reference 56 . 

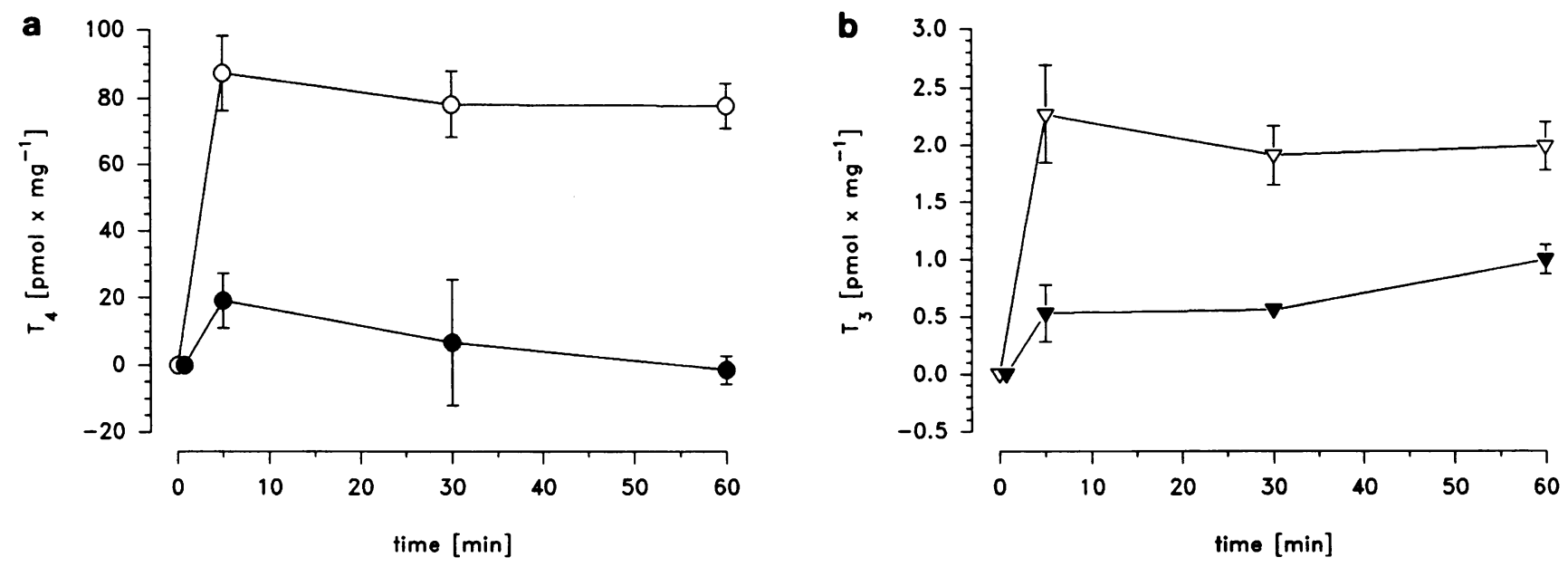

Figure 2. Time course of thyroid hormone release from TG by $\mathbf{J} 774$ cells (RIA). Thyroid hormone levels (mean \pm SE) in lysates (filled symbols) and supernatants (open symbols) of $\mathrm{J} 774$ cells before $(0 \mathrm{~min})$ and after $(5-60 \mathrm{~min})$ incubation with $\mathrm{TG}$ at $37^{\circ} \mathrm{C}$. Note different scaling of the $y$-axis for $\mathrm{T}_{4}(a$, circles $)$ and for $\mathrm{T}_{3}$ levels $(b$, triangles $)$, indicating that $\mathrm{T}_{4}$ is the main hormone released from TG by $\mathrm{J} 774$ cells. In the culture medium about four to five times more $T_{3}$ or $T_{4}$ were detected than in cells $(5 \mathrm{~min})$. At later time points $(30-60 \mathrm{~min})$ the cellular levels for $T_{4}$ decreased $\left(a\right.$, filled circles), whereas the cellular levels for $\mathrm{T}_{3}$ increased $(b$, filled triangles).

With longer chase periods ( $>30 \mathrm{~min}$ ) TG-containing small vesicles became increasingly detectable (Fig. $3 b^{\prime}$, arrowheads). We refer to such vesicles as lysosomes because they acquired the endocytosed ligand at later times (Fig. 3, $b$ and $b^{\prime}$ ) and because they contained Lamp-1 (Fig. 3, $c$ and $c^{\prime}$ ). Immunoelectron microscopy revealed luminal labeling for TG in lysosomes of $\mathrm{J} 774$ cells identified by the presence of $\mathrm{BSA}^{-\mathrm{Au}_{17}}$ (Fig. $4 d$, Lys). Such vesicles were often located near the tips of cellular extensions in bipolar cells (Fig. 3, $b$ and $b^{\prime}$ ). Because both markers, the endocytosed BSA- $\mathrm{Au}_{17}$ and the internalized TG, (detected by $\mathrm{Fab}-\mathrm{Au}_{5}$ ), were found together in large vacuoles (Fig. $4 c$, arrows), we conclude that these "mixed compartments" resulted from the fusion of lysosomes with endosomes.

Degradation of $T G$. Intracellular degradation was analyzed by incubation of $\mathrm{J} 774$ cells with radioiodinated TG at $37^{\circ} \mathrm{C}$ or $4^{\circ} \mathrm{C}$. Cell lysates were analyzed by SDS-PAGE and fluorography. At $4^{\circ} \mathrm{C}$ TG attached to the plasma membrane consisted of 12S- and 19S-TG, and some protein bands with higher electrophoretic mobility (Fig. 5, lane 1). Incubation of $\mathrm{J} 774$ cells with radioiodinated TG at $37^{\circ} \mathrm{C}(120 \mathrm{~min})$ resulted in the internalization of TG (see above) and in the accumulation of a $25-\mathrm{kD}$ degradation fragment (Fig. 5, lane 2, arrowhead), which was not observed at $4^{\circ} \mathrm{C}$.

When lysosomes isolated from $\mathrm{J} 774$ cells were lysed and incubated with TG for various time intervals at $37^{\circ} \mathrm{C}$, limited proteolysis of TG (Fig. 6, lane 1 ) was observed at $5 \mathrm{~min}$ (Fig. 6, lane 2) and $60 \mathrm{~min}$ (Fig. 6, lane 3) of incubation. Degradation of TG was noted within $4 \mathrm{~h}$ (Fig. 6, lane 4) of incubation.

The results also demonstrated that during the time intervals of maximum thyroid hormone release proteolysis of TG by J774 cells was limited. Thus, the fast process of thyroid hormone release preceded the slow process of lysosomal proteolysis of TG.

Sites of thyroid hormone release from $T G$. In principle, thyroid hormone release from TG by macrophages can occur at different sites, e.g., during proteolysis in endocytic compartments after internalization of TG or by extracellular degradation mediated by plasma membrane-bound or secreted proteases that act on TG before endocytosis.
Hormone release by secreted proteases. When long-term $(16 \mathrm{~h})$ conditioned media were incubated with TG at $37^{\circ} \mathrm{C}$, hormone release was detected $\left(8.1 \mathrm{pmol} \mathrm{T}_{4} / \mathrm{mg}\right.$ and $2.22 \mathrm{pmol}$ $\mathrm{T}_{3} / \mathrm{mg}$ ). This suggests that secreted proteases contributed to thyroid hormone release. To gain information on the nature of the secreted proteases, conditioned culture media were incubated with TG in the presence or absence of a protease inhibitor cocktail consisting of PMSF, aprotinin, and iodoacetamide. The results showed that the release of $T_{4}$ was completely inhibited in the presence of the inhibitor cocktail $\left(0.0 \mathrm{pmol} \mathrm{T}_{4} / \mathrm{mg}\right)$ and therefore mediated by serine and/or cysteine proteases. The release of $\mathrm{T}_{3}$ was lower $(0.85 \mathrm{pmol} \mathrm{T} / \mathrm{mg})$ but not completely inhibited by the protease inhibitors, indicating that the release of $T_{3}$ required the additional activity of aspartyl and/or metallo-proteases.

To quantitate the contribution of secreted proteases to thyroid hormone release during the initial incubation of cells with TG, conditioned culture media ( $5 \mathrm{~min}$ ) were incubated with TG in the absence or presence of cells at $37^{\circ} \mathrm{C}$ for a further 5 min. In the absence of cells, the release of $\mathrm{T}_{4}$ was observed $(0.4$ $\mathrm{pmol} / \mathrm{mg})$, whereas $T_{3}$ was not detectable $(0.0 \mathrm{pmol} / \mathrm{mg})$. In the presence of cells, the release of $T_{3}$ became detectable $(0.1$ $\mathrm{pmol} / \mathrm{mg}$ ) and the amount of $\mathrm{T}_{4}$ released from TG was much higher $(17.4 \mathrm{pmol} / \mathrm{mg})$ than in the absence of cells. The thyroid hormone content measured after incubation of TG with conditioned media reflected the hormone release by secreted proteases. When TG was added to cells in conditioned media the thyroid hormone contents reflected additional hormone release due to the action of cellular proteases. In conclusion, during the initial interaction of $\mathrm{J} 774$ cells with TG, only a minor amount $(\sim 2 \%)$ of $T_{4}$ was released by secreted proteases whereas no $T_{3}$ was detected.

Hormone release in endocytic compartments. $\mathrm{A}_{4} / \mathrm{T}_{3}$ ratio of 36 was determined in lysates of $\mathrm{J} 774$ cells at $5 \mathrm{~min}$ when TG reached endosomes. The ratio of $T_{4}$ to $T_{3}$ decreased to 15 at 60 min when TG had reached the lysosomes. Thyroid hormone reiease in endocytic compartments was affected by $\mathrm{NH}_{4} \mathrm{Cl}$ with inhibition of 38 and $84 \%\left(\mathrm{~T}_{4}\right)$ and of 67 and $93 \%\left(\mathrm{~T}_{3}\right)$ at 5 and $60 \mathrm{~min}$, respectively. The results show that an acidic $\mathrm{pH}$ facili- 

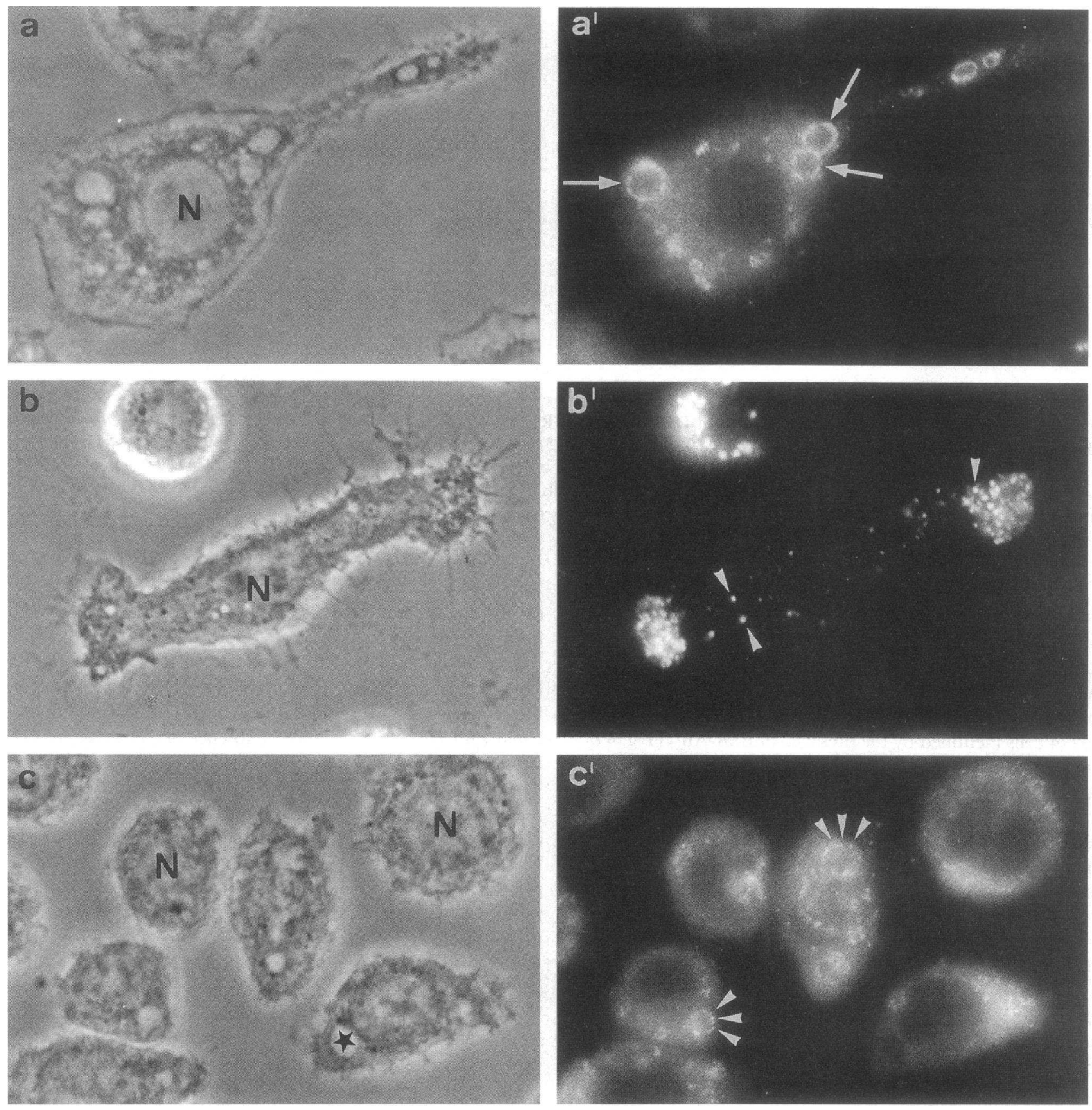

Figure 3. Endocytic compartments of $\mathrm{J} 774$ cells. Phase contrast $(a-c)$ and corresponding immunocytochemical detection of TG $\left(a^{\prime}\right.$ and $\left.b^{\prime}\right)$ and the lysosomal membrane glycoprotein Lamp-1 $\left(c^{\prime}\right)$ before ( $c$ and $\left.c^{\prime}\right)$ and after $\left(a-b^{\prime}\right)$ endocytosis of TG at $37^{\circ} \mathrm{C}$. TG was internalized within a 5-min pulse and cells were subsequently chased in TG-free media for $5 \mathrm{~min}\left(a\right.$ and $\left.a^{\prime}\right)$ and for $60 \mathrm{~min}\left(b\right.$ and $\left.b^{\prime}\right)$. TG was detectable in vacuoles of $\mathrm{J} 774$ cells within $5 \mathrm{~min}\left(a^{\prime}\right.$, arrows). Note that immunolabeling revealed TG associated with the membranes of these vacuoles $\left(a^{\prime}\right.$, arrows $)$.

They were not immunolabeled with antibodies against Lamp-1 ( $c^{\prime}$, see asterisk in $c$ ) but Lamp-1-positive small vesicles often surrounded the vacuoles ( $c^{\prime}$, arrowheads). With prolonged chase periods ( $60 \mathrm{~min} ; b$ and $\left.b^{\prime}\right)$ TG became detectable in small vesicles ( $b^{\prime}$, arrowheads) that accumulated near the tips of cellular extensions in bipolar J774 cells. $N$, nucleus. $\left(a\right.$ and $\left.a^{\prime}\right) \times 1,300 ;\left(b\right.$ and $\left.b^{\prime}\right) \times 1,250 ;\left(c\right.$ and $\left.c^{\prime}\right) \times 1,175$.

tated thyroid hormone release in various endocytic compartments. The $\mathrm{T}_{4} / \mathrm{T}_{3}$ ratios and the values of $\mathrm{NH}_{4} \mathrm{Cl}$ inhibition suggest that the preferential release of $\mathrm{T}_{4}$ occurred in early endocytic compartments and that of $\mathrm{T}_{3}$ in lysosomes.

Thyroid hormone transport. Unexpectedly, the values for thyroid hormones released from TG did not further increase after 5 min of incubation of cells with TG (cf. Fig. 2). We envisioned three possible reasons for this plateau in hormone release: (a) a loss of thyroid hormones due to experimental conditions, e.g., unspecific adsorption to the culture dish; $(b)$ a loss of thyroid hormones due to metabolism in $\mathrm{J} 774$ cells; and (c) saturation of thyroid hormone-releasing enzymes. To exclude the first two possibilities, thyroid hormones were added to cell-free media and to vital or formaldehyde-fixed cells. Thyroid hormone recovery was determined after incubation for time intervals from 5 to $60 \mathrm{~min}$ at $37^{\circ} \mathrm{C}$. In cell-free media a 

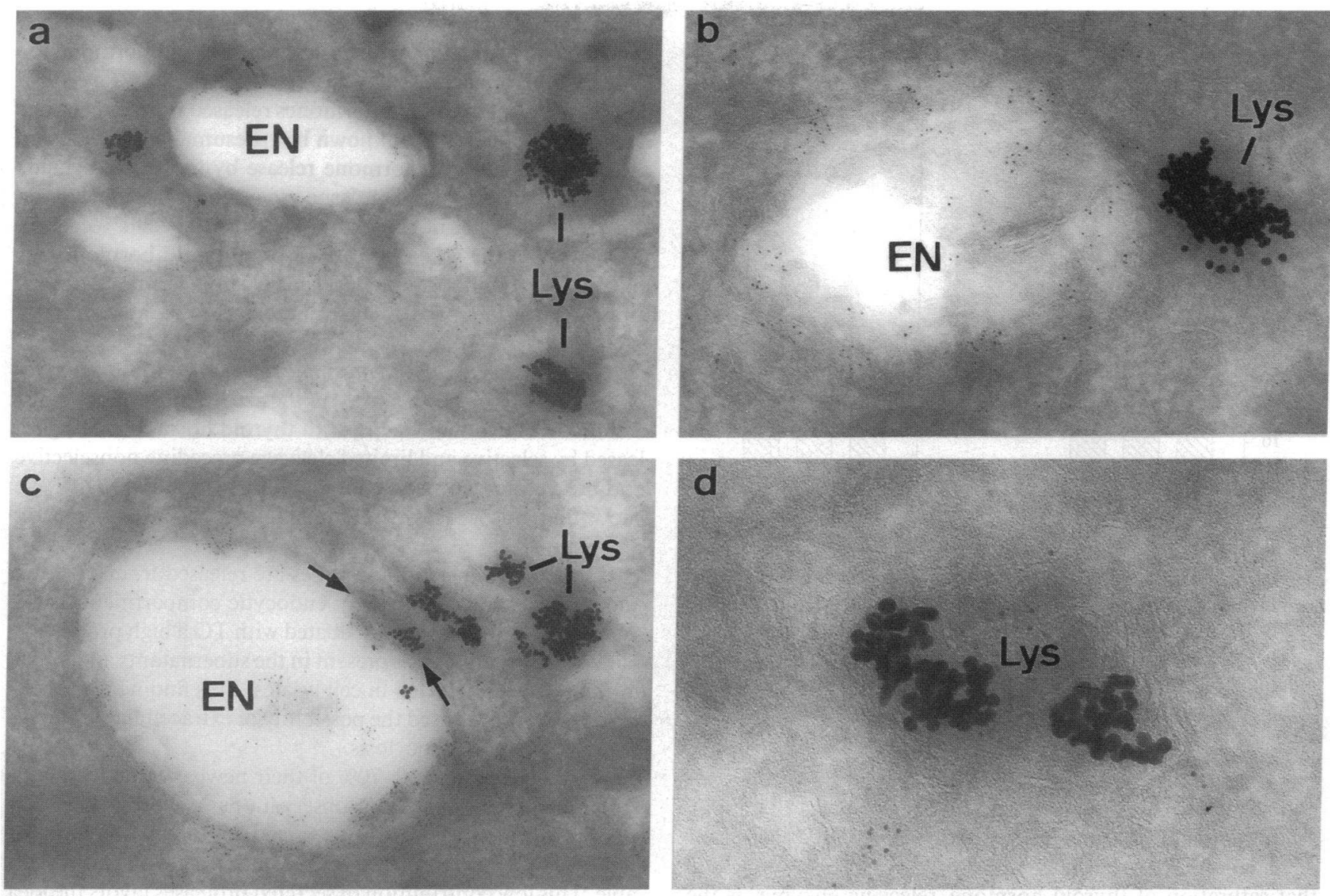

Figure 4. Endocytic pathway of TG in J774 cells. Cryosections from cells after endocytosis of TG for 5 min and chase periods of 5-60 min in TG-free media. Lysosomes $(L y s)$ have been previously labeled by endocytosis of $\mathrm{BSA}-\mathrm{Au}_{17}$ (9-h pulse, 20-h chase). Immunolabeling with anti-

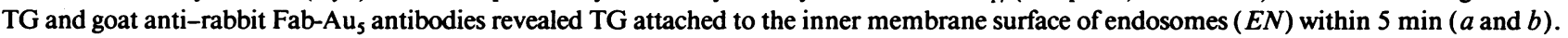
Prelabeled lysosomes were found in close apposition to TG-containing endosomes ( $a$ and $b$ ). In addition, both markers were detected together in large vacuoles $\left(c\right.$, arrows). After $60 \mathrm{~min}$, TG was detected in prelabeled BSA-Au ${ }_{17}$-containing lysosomes $(d)$. These results indicate accessibility of TG for lysosomal hydrolases within early stages of endocytosis. $(a) \times 32,300 ;(b) \times 67,500 ;(c) \times 40,000 ;(d) \times 117,000$.

loss of thyroid hormones was not observed, indicating that adsorption to the surfaces of the culture dishes was negligible (not shown), whereas media containing vital or formaldehyde-fixed cells showed a decline in the thyroid hormone content. The loss of hormones from the media corresponded to the hormone content detected in the cell lysates (Fig. 7, $a$ and $b$ ). Generally, no difference in the hormone contents of vital or formalde-

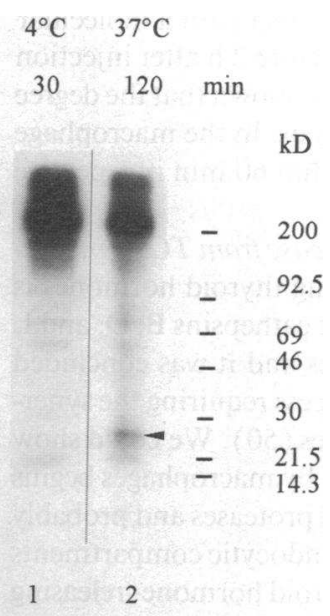

Figure 5. Limited proteolysis of ${ }^{125} \mathrm{I}-$ TG after endocytosis by $\mathbf{J 7 7 4}$ cells. SDS-PAGE and fluorography of $\mathrm{J} 774$ cell lysates after binding (lane 1 ) at $4^{\circ} \mathrm{C}(30 \mathrm{~min})$ and endocytosis (lane 2) at $37^{\circ} \mathrm{C}(120 \mathrm{~min})$ of ${ }^{125} \mathrm{I}-\mathrm{TG}$. Endocytosis resulted in the formation of a 25-kD fragment (arrowhead) that was not observed at $4^{\circ} \mathrm{C}$. Note that only limited proteolysis occurred at times of maximum thyroid hormone release. lysosomal hydrolases

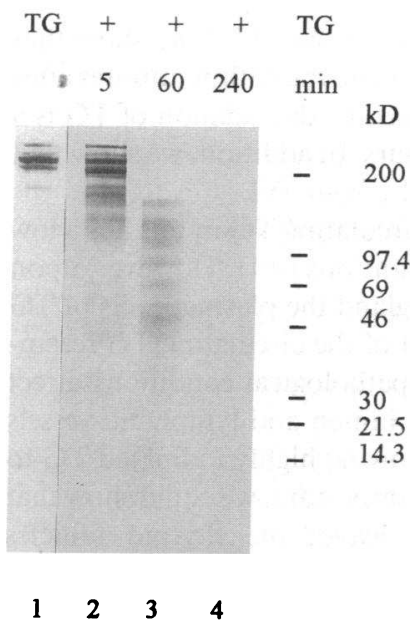

Figure 6. Degradation of TG by lysosomal hydrolases of J774 cells. SDS-PAGE and immunoblotting of TG (lane 1) incubated with lysosomal hydrolases isolated from $\mathrm{J} 774$ cells for $5 \mathrm{~min}$ (lane 2), $60 \mathrm{~min}$ (lane 3 ), and $4 \mathrm{~h}$ (lane 4 ) at $37^{\circ} \mathrm{C}$. Note that time intervals of $4 \mathrm{~h}$ were needed for degradation of TG. Cross-reactivities of antibodies against TG with lysosomal hydrolases were not observed (not shown). 

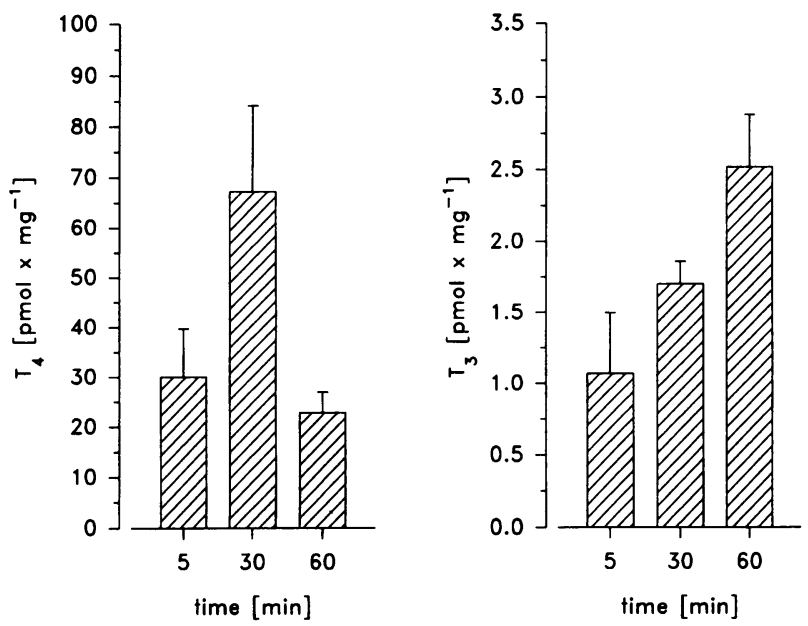

Figure 7. Accumulation of $\mathrm{T}_{3}$ and export of $\mathrm{T}_{4}$ by $\mathrm{J} 774$ cells. Thyroid hormone levels (mean $\pm \mathrm{SE}$ ) of cell lysates after incubation of vital $J 774$ cells with $T_{3}$ and $T_{4}$ for $5-60$ min at $37^{\circ} \mathrm{C}$. Note that $T_{3}$ levels of cell lysates increased with time $(b)$, indicating intracellular accumulation of $T_{3}$. In contrast, $T_{4}$ levels in the cell lysates increased within $30 \mathrm{~min}$ and decreased again at $60 \mathrm{~min}(a)$, indicating that $\mathrm{T}_{4}$ is exported into the medium.

hyde-fixed cells was observed with $5.5 \mathrm{fmol} \mathrm{T}_{3}$ and $152 \mathrm{fmol} \mathrm{T}_{4}$ accumulating in $10^{6}$ cells $/ \mathrm{min}$, thereby ruling out a significant degradation of thyroid hormones by $\mathbf{J} 774$ cells. We conclude that saturation of thyroid hormone-releasing enzymes is the most likely mechanism underlying the plateau formation in hormone release from TG. The $\mathrm{T}_{4}$ levels in vital cells, however, decreased again at $60 \mathrm{~min}$ (Fig. $7 \mathrm{a}$ ), suggesting that J774 cells acquired the ability to export $\mathrm{T}_{4}$.

\section{Discussion}

Increased concentrations of circulating TG are followed by an elevation of thyroid hormone levels resulting from the partial degradation of TG by unknown extrathyroidal mechanisms $(19,20,36-38)$. First indications that macrophages might be the cellular source for thyroid hormone release from circulating TG came from the ability of Kupffer cells to efficiently internalize TG (7) and from long-term incubation of macrophages with TG (39).

Using the mouse macrophage cell line $\mathrm{J} 774$ we show that hormone release is a fast process occurring within minutes after limited proteolysis of TG, whereas the degradation of TG is a slow process requiring several hours. In addition, we show that $\mathrm{J} 774$ cells release preferentially $\mathrm{T}_{4}$ from $\mathrm{TG}$.

It is generally assumed that circulating TG in rats has a low degree of iodination in basal conditions (40). However, upon TSH stimulation of the thyroid gland the plasma levels of TG increased and the iodine content of the circulating TG resembled that of tissue TG (40). In pathological conditions direct continuities between the follicle lumen and lymphatic vessels have been described, thereby allowing highly iodinated TG to reach the circulation (41). Most important, we could show that under normal conditions TG leaves the thyroid follicles through a TSH-dependent transepithelial transport bypassing the lysosomes (8). Transcytosed TG reaches the circulation as an intact molecule in a state similar to luminal TG (10) and can efficiently function as a substrate for thyroid hormone release by macrophages.

The amount of thyroid hormones released from circulating TG by macrophages is unknown but presumably much lower as compared with the hormone release by the thyroid gland. However, we postulate that tissue macrophages in the liver or in other organs act in concentrating TG by specific receptors (18) and that the subsequent release of thyroid hormones results in increased hormone levels at locally circumscribed regions, such as the space of Dissé in the liver or at inflammatory sites.

Cellular sites of thyroid hormone release from $T G$ by macrophages. In thyrocytes it was hypothesized that degradation of TG involves two main steps, with thyroid hormones being released by selective and limited cleavage preceding nonselective and delayed proteolysis of the protein backbone $(42,43)$. We show that this process, in principle, occurs also in macrophages.

In the thyroid gland hormones are released from TG after endocytosis and proteolysis in endocytic compartments (44). When macrophages were incubated with TG a high proportion of thyroid hormones was present in the supernatants and only a minor part was detected in cell lysates. This finding was unexpected because it raised the possibility of extracellular proteolysis of TG before endocytosis.

J774 cells secrete $60-70 \%$ of their newly synthesized lysosomal hydrolases (45). Our observations, however, show that thyroid hormone release by secreted proteases accounts for only $\sim 2 \%$ of the total $T_{4}$, whereas no $T_{3}$ release was detectable. This low contribution of secreted proteases favors the idea that ectoproteases on the cell surface are involved in the fast process of thyroid hormone release from TG. Indeed, the incubation of isolated plasma membranes from $\mathrm{J} 774$ cells with TG is followed by the release of thyroid hormones and iodothyronines (Brix, K., unpublished observation).

Intracellular degradation after endocytosis of TG can occur in endosomes and lysosomes, since proteolytic activities were detected at all stages along the endocytic pathway in macrophages (46-48). We show that TG is accessible for lysosomal proteases at early stages of endocytosis and detectable in lysosomes at later stages (at $\sim 60 \mathrm{~min})$, whereas the degradation of radioiodinated TG was still incomplete at $2 \mathrm{~h}$ of endocytosis. Apparently, thyroid hormone release precedes degradation of the protein backbone of TG. Our results are in support of observations on the half-life of circulating TG in rats $(5.1 \mathrm{~h})$ and the finding that the first degradation product with a molecular mass of 60-70 kD cannot be detected before $2 \mathrm{~h}$ after injection of TG (15). Lamas and Ingbar (49) have shown that the degree of iodination affects the rate of proteolysis. In the macrophage system TG resisted the degradation within $60 \mathrm{~min}$ irrespective of the iodine content.

Mechanisms of thyroid hormone release from TG by macrophages. The nature of enzymes releasing thyroid hormones is still obscure. In vitro, it was shown that cathepsins $B, D$, and $L$ cleave TG near the hormonogenic sites and it was concluded that proteolysis of TG is a complex process requiring the synergistic action of various enzyme activities (50). We could show that thyroid hormone release from TG by macrophages begins extracellularly by the action of secreted proteases and probably of ectoproteases, and continues in the endocytic compartments ( see Fig. 8). Possible candidates for thyroid hormone-releasing 


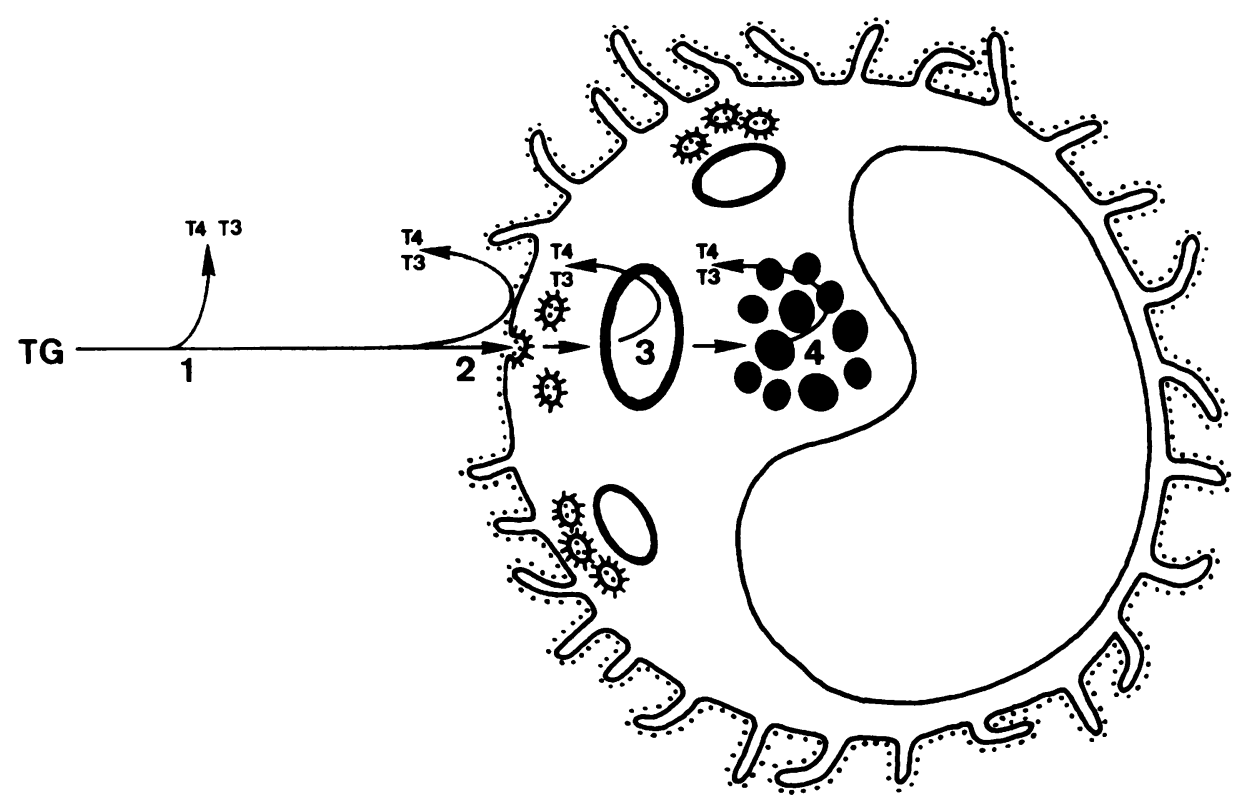

Figure 8. Extracellular and intracellular sites of thyroid hormone release from TG by macrophages. Schematic view summarizing the results on thyroid hormone release from TG by $\mathrm{J} 774$ macrophages. TG has access to macrophages and is concentrated from the extracellular space by a high-affinity receptor that mediates internalization of TG. Within 5 min TG reaches endosomes (3) and accumulates in lysosomes within $60 \mathrm{~min}$ (4). Thyroid hormone release occurs by extracellularly acting proteases ( 1 and 2 ) and continues in the compartments along the endocytic pathway ( 3 and 4). $T_{4}$ release occurs mainly by extracellular ( 1 ) and endosomal (3) proteolysis, whereas $T_{3}$ is released mainly in lysosomes (4). Ectoenzymes present at the cell surface of macrophages (2) contribute to the extracellular release of thyroid hormones. enzymes in macrophages are the secreted cathepsin $\mathrm{L}(51,52)$, ectoproteases on the plasma membrane (53), and various cathepsins in the endocytic compartments $(47,54,55)$.

The release of thyroid hormones from TG reached a plateau after 5 min of incubation of J774 cells with TG. Our observations allow the conclusion that saturation of thyroid hormone-releasing enzymes is the most likely mechanism underlying this plateau formation. Furthermore, we expected a rapid but limited release of thyroid hormones from TG since we have recently shown that endocytosis of TG by macrophages is a saturable process $(17,18)$. Because $T_{3}$ release occurs preferentially in more acidic compartments of $\mathrm{J} 774$ cells and the number of endocytosed TG molecules is limited, we expected considerably lower amounts of released $T_{3}$ as compared with $\mathrm{T}_{4}$. Indeed, our experiments have shown that $\mathrm{T}_{4}$ release exceeds that of $T_{3}$ by a factor of $\sim 37$.

\section{Acknowledgments}

We are indebted to Drs. H. Rosen and S. Gordon (University of Oxford, Oxford, England) for kindly providing the antibodies against lysosomal membrane glycoprotein Lamp-1. We thank Dr. W. Neumüller for discussion, Mrs. K. Kretschmann for excellent technical assistance, and Mrs. E. Krämer for photographical work.

The study was supported by the Deutsche Forschungsgemeinschaft (Sonderforschungsbereich 284) and by the Fonds der Chemischen Industrie.

\section{References}

1. Hjort, T. 1961. Determination of serum-thyroglobulin by a haemagglutination-inhibition test. Lancet. i:1262-1264.

2. Assem, E. S. K. 1964. Thyroglobulin in the serum of parturient women and newborn infants. Lancet. i:139-141.

3. Roitt, I. M., and G. Torrigiani. 1967. Identification and estimation of undegraded thyroglobulin in human serum. Endocrinology. 81:421-429.

4. Van Herle, A. J., and D. G. Brown. 1990. Thyroglobulin in benign and malignant thyroid disease. In Thyroid Disease: Endocrinology, Surgery, Nuclear Medicine, and Radiotherapy. S. A. Falk, editor. Raven Press, Ltd., New York. 473-484.
5. De Baets, M. H., A. M. Janssens, C. G. Romball, and W. O. Weigle. 1983. A radioimmunoassay for murine thyroglobulin in serum: age-related increase of serum thyroglobulin levels in AKR/J mice. Endocrinology. 112:1788-1795.

6. Van Herle, A. J., H. Klandorf, and R. P. Uller. 1975. A radioimmunoassay for serum rat thyroglobulin. Physiologic and pharmacological studies. J. Clin. Invest. 56:1073-1081.

7. Uller, R. P., A. J. Van Herle, and I. J. Chopra. 1973. Comparison of alterations in circulating thyroglobulin, triiodothyronine and thyroxine in response to exogenous (bovine) and endogenous (human) thyrotropin. J. Clin. Endocrinol. \& Metab. 37:741-745.

8. Herzog, V. 1983. Transcytosis of thyroid follicle cells. J. Cell Biol. 97:607617.

9. Herzog, V. 1984. Pathways of endocytosis in thyroid follicle cells. Int. Rev. Cytol. 91:107-139.

10. Romagnoli, P., and V. Herzog. 1991. Transcytosis in thyroid follicle cells: regulation and implications for thyroglobulin transport. Exp. Cell Res. 194:202209.

11. Spiro, M. J., and R. G. Spiro. 1985. Synthesis and processing of thyroglobulin carbohydrate units. In Thyroglobulin: The Prothyroid Hormone (Progress in Endocrine Research and Therapy, Vol. 2). M. C. Eggo and G. N. Burrow, editors. Raven Press, Ltd., New York. 103-113.

12. Morell, A. G., G. Gregoriadis, I. H. Scheinberg, J. Hickman, and G. Ashwell. 1971. The role of sialic acid in determining the survival of glycoproteins in the circulation. J. Biol. Chem. 246:1461-1467.

13. Izumi, M., and P. R. Larsen. 1978. Metabolic clearance of endogenous and radioiodinated thyroglobulin in rats. Endocrinology. 103:96-100.

14. Ikekubo, K., R. Pervos, and A. B. Schneider. 1980. Clearance of normal and tumor-related thyroglobulin from the circulation of rats: role of the terminal sialic acid residues. Metabolism. 29:673-681.

15. Taura, M., S. Yamashita, I. Kubo, M. Izumi, and S. Nagataki. 1985 Degradation of circulating thyroglobulin. Metabolism. 34:945-948.

16. Ashwell, G., and J. Harford. 1982. Carbohydrate-specific receptors of the liver. Annu. Rev. Biochem. 51:531-554.

17. Brix, K., and V. Herzog. 1991. Endocytosis of thyroglobulin and thyroid hormone formation by macrophages. J. Cell Biol. 115:261a (Abstr.)

18. Brix, K., W. Summa, and V. Herzog. 1992. Macrophages (J774) generate thyroid hormones after endocytosis of thyroglobulin. Eur. J. Cell Biol. 57 (Suppl. 36):12. (Abstr.)

19. Taura, M., M. Izumi, and S. Nagataki. 1986. Release of thyroid hormone from circulating thyroglobulin in the rat. Acta Endocrinol. 111:209-212.

20. Van Herle, A. J. 1986. Measurement and clinical significance of thyroglobulin in serum and body fluids. In The Thyroid. S. H. Ingbar and L. B. Braverman, editors. J. B. Lippincott Company, Philadelphia. 534-545.

21. Ralph, P., J. Prichard, and M. Cohn. 1975. Reticulum cell sarcoma: an effector cell in antibody-dependent cell-mediated immunity. J. Immunol. 114:898-905.

22. Markwell, M. A. K. 1982. A new solid-state reagent to iodinate proteins. I. Conditions for the efficient labeling of antiserum. Anal. Biochem. 125:427-432. 
23. Johnstone, A., and R. Thorpe. 1982. Immunocytochemistry in Practice. Blackwell Scientific Publications Ltd., Oxford. 298 pp.

24. Salvesen, G., and H. Nagase. 1990. Inhibition of proteolytic enzymes. In Proteolytic Enzymes. A practical approach. R. J. Beynon and J. S. Bond, editors. IRL Press Ltd., Oxford. 83-104.

25. Bradford, M. M. 1976. A rapid and sensitive method for the quantitation of microgram quantities of protein utilizing the principle of protein-dye binding. Anal. Biochem. 72:248-254.

26. Laemmli, U. K. 1970. Cleavage of structural proteins during the assembly of the head of bacteriophage T4. Nature (Lond.). 227:680-685.

27. Heukeshoven, J., and R. Dernick. 1988. Improved silver staining procedure for fast staining in PhastSystem development unit. I. Staining of sodium dodecyl sulfate gels. Electrophoresis. 9:28-32.

28. Towbin, H., T. Staehelin, and J. Gordon. 1979. Electrophoretic transfer of proteins from polyacrylamide gels to nitrocellulose sheets: procedure and some applications. Proc. Natl. Acad. Sci. USA. 76:4350-4354.

29. Rabinowitz, S., H. Horstmann, S. Gordon, and G. Griffiths. 1992. Immunocytochemical characterization of the endocytic and phagolysosomal compartments in peritoneal macrophages. J. Cell Biol. 116:95-112.

30. Tokuyasu, K. T. 1973. A technique for ultracryotomy of cell suspensions and tissues. J. Cell Biol. 57:551-565.

31. Slot, J. W., and H. J. Geuze. 1981. Sizing of protein A colloidal gold probes for immunoelectron microscopy. J. Cell Biol. 90:533-536.

32. Samuels, H. H., F. Stanley, and J. Casanova. 1979. Depletion of L-3,5,3'triiodothyronine and L-thyroxine in euthyroid calf serum for use in cell culture studies of the action of thyroid hormone. Endocrinology. 105:80-85.

33. Krebs, K. G., D. Heusser, and H. Wimmer. 1969. Spray Reagents. In Thin-Layer Chromatography. A Laboratory Handbook. E. Stahl, editor. Springer-Verlag, Berlin, Heidelberg. 854-908.

34. Van Herle, A. J., R. P. Uller, N. L. Matthews, and J. Brown. 1973. Radioimmunoassay for measurement of thyroglobulin in human serum. J. Clin. Invest 52:1320-1327.

35. Thomas, P. S., and M. N. Farquhar. 1978. Specific measurement of DNA in nuclei and nucleic acids using diaminobenzoic acid. Anal. Biochem. 89:35-44.

36. Brown, F., and H. Jackson. 1956. The fate of ${ }^{131} \mathrm{I}$-labelled homologous and heterologous thyroglobulins in the rat, dog, monkey and rabbit. Biochem. $J$. 62:295-301.

37. Tatumi, K., Y. Suzuki, and H. Sinohara. 1981. Production of the thyroid hormone from thyroglobulin injected intravenously into the thyroidectomized rat. Biochem. Int. 2:167-172.

38. Tatumi, K., Y. Suzuki, and H. Sinohara. 1979. Clearance of circulating desialylated thyroglobulins in the rat. Biochim. Biophys. Acta. 583:504-511.

39. Hoddevik, G., and R. Seljelid. 1975. The uptake and degradation of sheep thyroglobulin by macrophages in vitro. Exp. Cell Res. 93:152-158.

40. Schneider, A. B. 1985. Physical characterization of serum thyroglobulin Implications for the mechanism of secretion into the circulation. In Thyroglobulin: The Prothyroid Hormone (Progress in Endocrine Research and Therapy, Vol. 2). M. C. Eggo and G. N. Burrow, editors. Raven Press, Ltd., New York. 297-306.
41. Gebel, F., and H. Studer. 1984. Malignant follicles of a differentiated thyroid carcinoma releasing iodinated thyroglobulin into the lymphatic vessels. Clin. Endocrinol. 20:457-462.

42. Rousset, B., and R. Mornex. 1991. The thyroid hormone secretory pathway: current dogmas and alternative hypotheses. Mol. Cell. Endocrinol. 78:C89C93.

43. Rousset, B., S. Selmi, H. Bornet, P. Bourgeat, R. Rabilloud, and Y. Munari-Silem. 1989. Thyroid hormone residues are released from thyroglobulin with only limited alteration of the thyroglobulin structure. J. Biol. Chem. 264:12620 12626.

44. Fujita, H. 1988. Functional morphology of the thyroid. Int. Rev. Cytol. 113:145-185.

45. Gabel, C. A., D. E. Goldberg, and St. Kornfeld. 1983. Identification and characterization of cells deficient in the mannose 6-phosphate receptor: evidence for an alternate pathway for lysosomal enzyme targeting. Proc. Natl. Acad. Sci. USA. 80:775-779.

46. Diment, S., and P. D. Stahl. 1985. Macrophages endosomes contain proteases which degrade endocytosed protein ligand. J. Biol. Chem. 260:1531115317.

47. Rodman, J. S., M. A. Levy, S. Diment, and P. D. Stahl. 1990. Immunolocalization of endosomal cathepsin $\mathrm{D}$ in rabbit alveolar macrophages. J. Leukocyte Biol. 48:116-122.

48. Mayorga, L. S., R. Diaz, and P. D. Stahl. 1989. Reconstitution of endosomal proteolysis in a cell-free system. Transfer of immune complexes internalized via Fc receptors to an endosomal proteolytic compartment. J. Biol. Chem. 264:5392-5399.

49. Lamas, L., and S. H. Ingbar. 1978. The effect of varying iodine content on the suspectibility of thyroglobulin to hydrolysis by thyroid acid protease. Endocrinology. 102:188-197.

50. Dunn, A. D., H. E. Crutchfield, and J. T. Dunn. 1991. Thyroglobulin processing by thyroidal proteases. Major sites of cleavage by cathepsins B, D, and L. J. Biol. Chem. 266:20198-20204.

51. Jessup, W., and R. T. Dean. 1980. Spontaneous lysosomal enzyme secretion by a murine macrophage-like cell line. Biochem. J. 190:847-850.

52. Portnoy, D. A., A. H. Erickson, J. Kochan, J. V. Ravetch, and J. C. Unkeless. 1986. Cloning and characterization of a mouse cysteine proteinase. $J$. Biol. Chem. 261:14697-14703.

53. Bauvois, B., J. Sanceau, and J. Wietzerbin. 1992. Human U937 cell surface peptidase activities: characterization and degradative effect on tumor necrosis factor-alpha. Eur. J. Immunol. 22:923-930.

54. Diment, S., M. S. Leech, and P. D. Stahl. 1988. Cathepsin D is membraneassociated in macrophage endosomes. J. Biol. Chem. 263:6901-6907.

55. Muno, D., N. Sutoh, T. Watanabe, Y. Uchiyama, and E. Kominami. 1990. Effect of metabolic alterations on the density and the contents of cathepsins B, H and L of lysosomes in rat macrophages. Eur. J. Biochem. 191:91-98.

56. Mercken, L., M.-J. Simons, St. Swillens, M. Massaer, and G. Vassart. 1985. Primary structure of bovine thyroglobulin deduced from the sequence of its 8,431-base complementary DNA. Nature (Lond.). 316:647-651. 